\title{
Non-invasive ventilation in prehospital settings
}

\author{
Georg Röggla $\cdot$ Bernadetta Moser $\cdot$ Berthold Moser
}

Received: 19 December 2012/ Accepted: 23 January 2013/Published online: 13 February 2013

(C) SIMI 2013

Dear Editor,

We read Katherine Margaret Bergs and co-authors' review on non-invasive ventilation (NIV) with great interest [1]. The authors focus on NIV in a hospital setting. As an amendment to this review, we would like to draw attention to the fact that NIV has successfully crossed the border to prehospital use in the past few years. NIV is increasingly being used for the treatment of severe respiratory distress in prehospital settings [2]. This technique has even been used successfully in medical emergencies in really remote places at high altitude in mountain medicine $[3,4]$. We think the prehospital use of NIV deserves growing interest.

Conflict of interest None.

\section{References}

1. Berg KM, Clardy P, Donnino MP (2012) Non-invasive ventilation for acute respiratory failure: a review of the literature and current guidelines. Intern Emerg Med 7:539-545

2. Williams B, Boyle M, Robertson N, Giddings C et al (2012) When pressure is positive: a literature review of the prehospital use of continuous positive airway pressure. Prehosp Disaster Med 9:1-10

3. Schoene RB, Roach RC, Hackett PH, Harrison G, Mills WJ Jr et al (1985) High altitude pulmonary oedema and exercise at 4,400 meters on Mount McKinley. Effect of expiratory positive airway pressure. Chest 87:330-333

4. Koch RO, Hinterhuber L, Faulhaber M, Gatterer H, Graupner S, Muenzel K, Burtscher M et al (2009) A successful therapy of highaltitude pulmonary oedema with a CPAP helmet on Lenin Peak. Clin J Sport Med 19:72-73
G. Röggla $(\bowtie)$

Department of Internal Medicine, Landesklinikum

Neunkirchen, Neunkirchen, Austria

e-mail: georg.roeggla@neunkirchen.lknoe.at

B. Moser

Department of Intensive Care Medicine,

Ospedale di Bolzano, Bolzano, Italy

B. Moser

Department of Anaesthesiology, Kantonsspital St.

Gallen, St. Gallen, Switzerland 